Atmos. Chem. Phys., 13, 12257-12270, 2013

www.atmos-chem-phys.net/13/12257/2013/

doi:10.5194/acp-13-12257-2013

(c) Author(s) 2013. CC Attribution 3.0 License.

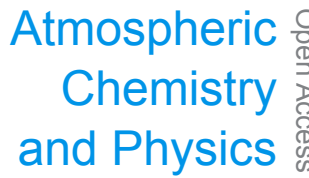

\title{
Black carbon over the South China Sea and in various continental locations in South China
}

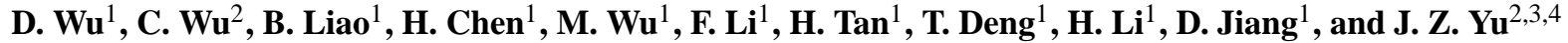 \\ ${ }^{1}$ Institute of Tropical and Marine Meteorology, CMA, Guangzhou 510080, China \\ ${ }^{2}$ Division of Environment, Hong Kong University of Science and Technology, Clear Water Bay, Kowloon, Hong Kong, China \\ ${ }^{3}$ Atmospheric Research Centre, Fok Ying Tung Graduate School, Hong Kong University of Science and Technology, Nansha, \\ Guangzhou, China \\ ${ }^{4}$ Department of Chemistry, Hong Kong University of Science and Technology, Clear Water Bay, Kowloon, Hong Kong, China
}

Correspondence to: D. Wu (wudui@grmc.gov.cn) and J. Z. Yu (chjianyu@ust.hk)

Received: 13 May 2013 - Published in Atmos. Chem. Phys. Discuss.: 1 July 2013

Revised: 25 October 2013 - Accepted: 7 November 2013 - Published: 17 December 2013

\begin{abstract}
Black carbon (BC) is an important atmospheric constituent as an air pollutant and as a climate forcer. To our knowledge, field measurements of $\mathrm{BC}$ have not been reported over the South China Sea. Observations of light-absorption coefficients $\left(\sigma_{\mathrm{abs}}\right)$ and $\mathrm{BC}$ concentrations by Aethalometer were conducted on Yongxing Island in the South China Sea and at five continental sites in the Pearl River delta (PRD) region, South China, in two periods: 16 May-20 June 2008 in the rainy season and 12 December 2008-8 January 2009 in the dry season. At the oceanic site, the daily average $\mathrm{BC}$ concentrations varied from 0.28 to $2.14 \mu \mathrm{g} \mathrm{m} \mathrm{m}^{-3}$ and variations of BC were small between the two periods $(0.67$ in the dry season sampling period and $0.54 \mu \mathrm{g} \mathrm{m}^{-3}$ in the rainy season sampling period). Similarly, little difference in BC level was found at a rural site in PRD between the two sampling periods ( 2.88 and $2.62 \mu \mathrm{g} \mathrm{m}^{-3}$ ). At the PRD urban sites, the daily average concentration of $\mathrm{BC}$ ranged from 1.56 to $37.9 \mu \mathrm{g} \mathrm{m}^{-3}$, higher in the dry season sampling pe$\operatorname{riod}\left(12.31 \mu \mathrm{g} \mathrm{m}^{-3}\right)$ and lower in the rainy season sampling period $\left(6.17 \mu^{-3} \mathrm{~m}^{-3}\right)$. The observed average $\sigma_{\text {abs }}$ values in rainy vs. dry season sampling periods are 119 vs. $62 \mathrm{Mm}^{-1}$ at the PRD urban sites, 29 vs. $26 \mathrm{Mm}^{-1}$ at the PRD background site, and 8.4 vs. $7.2 \mathrm{Mm}^{-1}$ at the marine site. At urban/suburban PRD sites, BC was observed to have a diurnal pattern of higher concentrations at night and at the urban sites a small peak in the early morning rush hour.
\end{abstract}

\section{Introduction}

Aerosol, as an important climate forcer, has attracted increasing attention in the atmospheric research community (Lohmann and Lesins, 2002; Menon et al., 2002; Penner et al., 2004). Atmospheric aerosols scatter and absorb solar radiation, thus significantly impacting the climate (Babu and Moorthy, 2001; Reddy and Venkataraman, 2000; Tao et al., 2012). Black carbon (BC) is an important component of atmospheric aerosols, affecting visibility, cloud formation, cloud cover and lifetime. IPCC started reporting radiative forcing due to $\mathrm{BC}$ aerosol since its second report (IPCC, 1996). The heating effect of $\mathrm{BC}$ aerosols may offset the cooling effect of sulfate and mineral aerosols (Andreae, 2001). If the mixing state of $\mathrm{BC}$ is taken into account, the radiative forcing of $\mathrm{BC}$ is estimated to be sufficiently strong to make $\mathrm{BC}$ the third most significant global warming contributor after $\mathrm{CO}_{2}$ and $\mathrm{CH}_{4}$ (Jacobson, 2001). A more recent study suggests $\mathrm{BC}$ is now possibly the second largest "global average warming agent" even ahead of methane (Cohen and Wang, 2013). BC aerosols could also have direct and indirect impacts on regional climate change (Ramanathan and Carmichael, 2008; Wang, 2013).

Since 1990s, a large body of observational data of BC aerosols in China has accumulated through field measurements. Tang et al. (1999) reported short-term observations of BC concentrations in Lin'an (a background station) in 1991 and in the Lasha area in 1998. Wang et al. (2002) measured $\mathrm{BC}$ concentrations in the northern suburbs of Beijing 
in 1992 and in the period of 1996-2001. In 1994, China's first global background atmospheric observatory was established in the Mt. Waliguan Mountains of Qinghai at $3810 \mathrm{~m}$ above sea level (a.s.l.), and the research carried out there has produced valuable findings related to BC (Qin et al., 2001). Chi et al. (2000) reported seasonal variation in abundance of elemental carbon (EC) in Beijing measured using a CHN analyzer. They found that higher EC in winter may be related to heating. Research in Qiqihar City found a similar seasonal variation pattern (Sun et al., 1997). Zhu et al. (1996) studied EC particle size distributions in Pudong, Shanghai. Cao et al. (2004) reported high organic carbon (OC) and EC concentrations in $\mathrm{PM}_{10}$ and $\mathrm{PM}_{2.5}$ across the Pearl River delta (PRD) region, measured using the IMPROVE protocol on a DRI carbon analyzer. Their results suggested significant impact of emissions from motor vehicles on ambient EC loadings (Cao et al., 2004). (Lou et al., 2005) measured $\mathrm{BC}$ in $\mathrm{PM}_{2.5}, \mathrm{PM}_{10}$ and TSP in Beijing using a filterbased light-absorption technique and found that most $\mathrm{BC}$ was in $\mathrm{PM}_{2.5}$. In late 2003, our group launched light-absorption measurement using Aethalometers (Magee Scientific Company, Berkeley, CA, USA) and filter-based EC measurement by thermal/optical analysis in the PRD region.

Asian BC aerosol also attracted attention of scientists worldwide due to its widespread and increasing atmospheric abundance. In 1999, European and American scientists found that southern Asia is often shrouded in a brown cloud of aerosols $3 \mathrm{~km}$ thick, referred to as the Asian brown cloud by many researchers (Ramanathan et al., 2002; Engling and Gelencser, 2010). In China, this phenomenon is often simply referred to as "haze" (Wu, 2005; Wu et al., 2005, 2007). Later, the similar phenomenon was found over every continent, more commonly known as the atmospheric brown cloud. The widespread presence of $\mathrm{BC}$ suggests that the role of $\mathrm{BC}$ as a warming force needs to be studied in order for the assessment of aerosol's role in global and regional climate change (Ramanathan and Carmichael, 2008) and for the attribution of contributions by individual countries. It has become clear that high-resolution spatial and temporal observations of radiation parameters of aerosol are essential data for assessment of the impact of Chinese aerosols on global and regional climate change.

In this work, we report $\mathrm{BC}$ and aerosol light-absorption measurements by Aethalometers in May-June 2008 in the rainy season and in December 2008-January 2009 in the dry season and their variations in these two sampling periods in a remote location over the South China Sea (SCS) and at six continental locations in South China. The marine location is Yongxing Island (YX) of the Xisha Islands in SCS. The continental locations include Nancun (NC), Panyu (PY), Xinken (XK) and Mt. Maofeng (Maofengshan (MFS) in Chinese), Dongguan (DG) in the PRD region in Guangdong Province and Yangshuo (YS) in Guangxi Zhuang Autonomous Region. PRD, the second largest delta in China, has been one of the fastest growing economic areas for nearly $30 \mathrm{yr}$ and among the most polluted areas in China. PRD has a total land area of $8000 \mathrm{~km}^{2}$ and a high population density. It is home to multiple mega cities including Guangzhou, Hong Kong, Shenzhen, Dongguan, Zhuhai, and Foshan. The urbanization in PRD has led to vegetation reduction, increased demand in transportation, and blooming of township enterprises, which in turn have resulted in increasingly frequent air pollution episodes (Wu et al., 2005).

Southern Mainland China is in a subtropical monsoon climate and the northern part of SCS is in a tropical monsoon climate. This region is influenced by two different monsoons, that is, SCS monsoon and northeast monsoon. April to May is the transition period of the northeast monsoon to the SCS monsoon; from June to September is the SCS monsoondominated period; October is the transition period of the SCS monsoon to the northeast monsoon; November to March is the northeast monsoon-dominated period. October to April in the following year is the dry season in southern China as a result of the controlling influence of the northeast monsoon. May to September is the rainy season due to the dominant influence of the SCS monsoon.

\section{Field observations}

\subsection{Sampling locations}

The Institute of Tropical and Marine Meteorology (ITMM) started to establish a monitoring network for atmospheric compositions over the PRD in 2003, and since that time a total of nine monitoring stations have been established. The observations presented in this paper include data from five long-term stations (NC, PY, XK, MFS, and DG) in PRD and two short-term stations outside PRD in South China. The station locations are shown in Fig. 1. Among the stations, NC, PY, XK and MFS are located in different districts in the city Guangzhou, the biggest mega-city in southern China. MFS is located on the top of Mt. Maofeng (535 m a.s.1.) and $20 \mathrm{~km}$ northeast to downtown Guangzhou. MFS, due to its high altitude and its rural location, represents the background condition of the PRD region. NC is a suburban site in the center of PRD, situated on the top of the highest peak (141 m a.s.l.) in Guangzhou's Panyu district. At $141 \mathrm{~m}$ a.s.l., this station is less impacted by ground-level local emissions, thus approximately representing the average atmospheric mixing characteristics in the PRD region. PY is an urban surface site and $7 \mathrm{~km}$ southwest to the NC station, representing urban conditions in Guangzhou. Due to a busy road only $140 \mathrm{~m}$ away from the station, significant influence of vehicular emissions is expected for the PY site. XK is a rural surface site, $60 \mathrm{~km}$ south to downtown Guangzhou. The prevailing northerly winds in the dry season make XK a receptor site of pollution in Guangzhou. DG is in a suburban neighborhood in the city Dongguan, one of the largest manufacturing centers in China. 
The two short-term observation stations are YS in Guangxi and YX Island in the middle of the South China Sea. YS is a small tourist city, surrounded by mining and metallurgical industries in the area. YX Island has an elevation of $5.6 \mathrm{~m}$, an area of $1.82 \mathrm{~km}^{2}$ and a population of $\sim 500$. The distance between YX Island and the center of PRD is approximately $730 \mathrm{~km}$. YX Island, owing to its geographical location, represents the average situation of northern part of the South China Sea. It is noted that YX island is on the route of marine vessels travelling from the Middle East, Africa and Europe to East Asia (Kaluza et al., 2010).

Observations reported in this work were carried out in two periods, 16 May-20 June 2008 in the rainy season and 12 December 2008-8 January 2009 in the dry season. Due to a lack of instruments, the same instrument was first deployed to YS from 16 May to 21 May then moved to YX for the remaining rainy season observation. The instrument remained at $\mathrm{YX}$ for the dry season observation, thus no observation was made at YS in the dry season.

\subsection{Sampling instruments}

In this study, six Aethalometers (AE-31-HS, AE-31-ER, and AE-16-ER, Magee Scientific Company, Berkeley, CA, USA) were deployed to determine aerosol absorption coefficients and $\mathrm{BC}$ concentrations. The AE-31 models measure light attenuation at seven wavelengths (i.e., 370, 470, 520, 590, 660, 880 , and $950 \mathrm{~nm}$ ). The AE-16 model has only one measurement channel at $880 \mathrm{~nm}$. These instruments were operated to provide continuous observations with a time resolution of $5 \mathrm{~min}$. Light attenuation measured by Aethalometers is dominated by $\mathrm{BC}$, as other constituents in the atmospheric particles absorb negligible amount of solar radiation at visible and infrared range (Moosmüller et al., 2009). BC concentration is then derived from the attenuation measurement by adopting specific values for attenuation cross section. The latter was obtained from comparison of attenuation and EC mass, which was determined to be 16.6 using a thermal analysis method developed in Lawrence Berkeley Laboratory (LBL) (also known as evolved gas analysis method) (Gundel et al., 1984) and used in the Aethalometers in reporting BC. It should be noted that Aethalometer $\mathrm{BC}$ is not equivalent to EC determined using the more widely adopted NIOSH or IMPROVE thermal/optical protocol. The multiplier 16.6 (specific attenuation cross section, SACS) is an empirical conversion factor that converts attenuation to mass concentration. SACS has a different physical meaning from mass absorption efficiency (MAE), which converts absorption to mass concentration. Attenuation reported by Aethalometers suffers from sampling artifacts due to aerosol loading, filter matrix, and scattering effect (Coen et al., 2010). Therefore correction is needed to obtain absorption coefficient $\left(\sigma_{\mathrm{abs}}\right)$ from attenuation. SACS already contains information of artifacts correction and MAE. For this reason, the value of SACS is usually larger ( $\sim 2$ times higher at $550 \mathrm{~nm})$ than MAE and
SACS cannot be directly compared with MAE reported in literature.

The Aethalometers were installed inside containers, with their inlets located $2 \mathrm{~m}$ above the container roof. A conductive silicone tubing (TSI, Shoreview, MN, USA) was used in the inlet system to minimize particle losses due to static charge. The Aethalometer deployed in YS and YX Island during the rainy season were equipped with a $2.5 \mu \mathrm{m}$ cyclone while a $10 \mu \mathrm{m}$ cyclone was used for the instruments at the other stations. The sampling flow rate was either 3 or $5 \mathrm{~L} \mathrm{~min}^{-1}$ (Wu et al., 2009). Routine flow calibration and blank tests were performed before sampling. A threshold value of attenuation for the periodical advancing of the filter tape was set at 100 .

Measurements of $\sigma_{\mathrm{abs}}$ and BC by the Aethalometers deployed in this study are applied for a correction factor derived from an inter-instrument comparison exercise. In 2004, we made two sets of side-by-side observations, one set using an Aethalometer $(880 \mathrm{~nm})$ and a photo-acoustic spectrometer (PAS, $532 \mathrm{~nm}$ ) from the Max Planck Institute in a downtown location in Guangzhou, and the second set using an Aethalometer and a Multi-Angle Absorption Photometry (Carusso/MAAP, $637 \mathrm{~nm}$ ) in a rural location near Guangzhou at the same time. The photo-acoustic method is more accurate in determining light absorption than the filterbased method, which may be subject to sampling artifacts linked to aerosol loading, filter matrix, and scattering effect (Coen et al., 2010). The light-absorption measurement between Aethalometer and PAS is well correlated and an empirical formula as shown below is obtained (Wu et al., 2009):

$\sigma_{\mathrm{PAS}, 532 \mathrm{~nm}}=0.51 \sigma_{\mathrm{AE}, 880 \mathrm{~nm}}+0.82$,

where $\sigma_{\mathrm{PAS}, 532 \mathrm{~nm}}$ is the light-absorption coefficient at $532 \mathrm{~nm}$ measured by PAS and $\sigma_{\mathrm{AE}, 880 \mathrm{~nm}}$ is the light-absorption coefficient at $880 \mathrm{~nm}$ measured by the Aethalometer. Similarly, an empirical formula was obtained to relate $\mathrm{BC}$ mass measurements by MAAP and the Aethalometer (Wu et al., 2009):

$\mathrm{BC}_{\mathrm{MAAP}}=0.897 \times \mathrm{BC}_{\mathrm{AE}}-0.062$.

$\sigma_{\text {abs }}$ reported in this work has been corrected with Eq. (1) while BC mass has been corrected using Eq. (2).

Aethalometers report both $\sigma_{\mathrm{abs}}$ and $\mathrm{BC}$. It is important to keep in mind that $\sigma_{\text {abs }}$ is what Aethalometers directly measure, while a BC measurement by an Aethalometer is derived from $\sigma_{\text {abs }}$ measurements, assuming that mass absorption efficiency (MAE) of $\mathrm{BC}$ aerosol is a constant during the sampling period. However, in reality MAE varies in time and space, depending on the mixing state of $\mathrm{BC}$ (Bond and Bergstrom, 2006). As a result, $\mathrm{BC}$ concentration data have additional uncertainties due to the uncertainty introduced by the constant multiplier (MAE). Data in this paper are mainly 


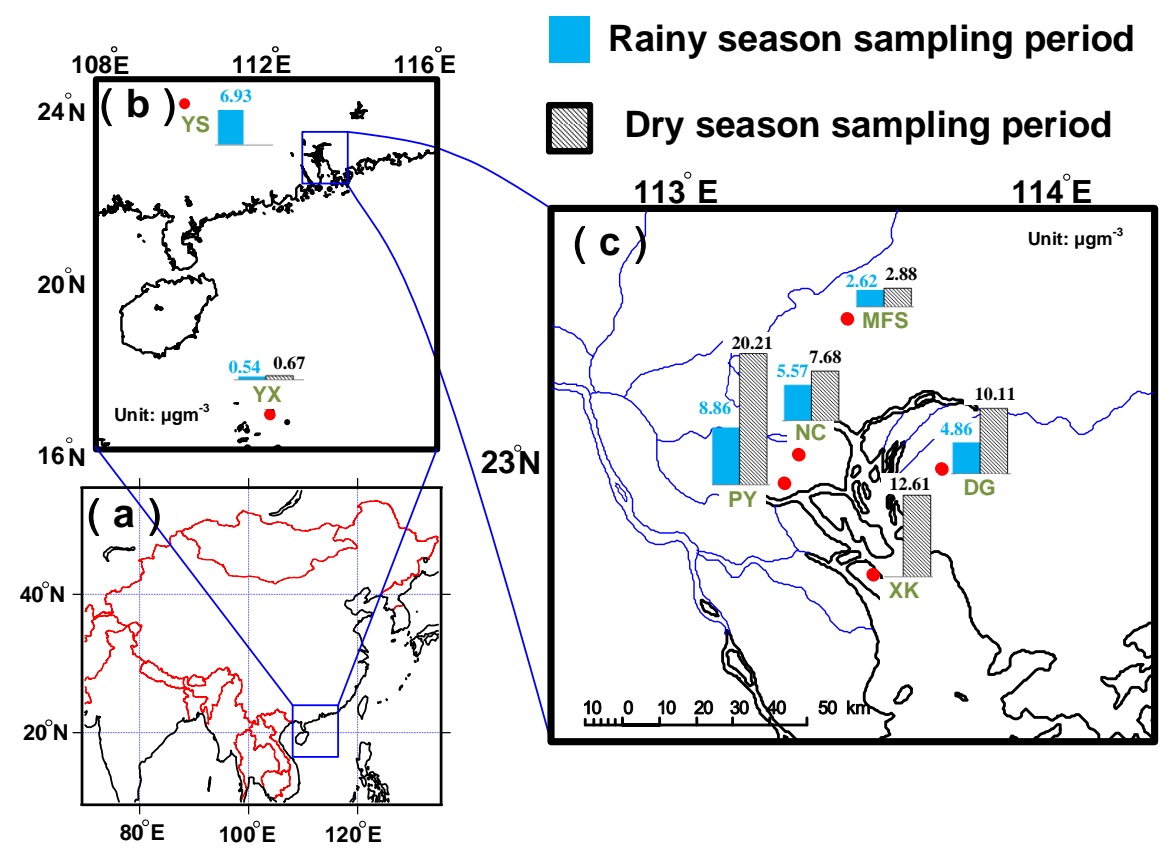

\begin{tabular}{ccccc}
\hline Location & Type & Latitude & Longitude & Elevation (m) \\
\hline Yongxing island (YX), SCS & Oceanic rural & $16.83^{\circ} \mathrm{N}$ & $112.33^{\circ} \mathrm{E}$ & 5.6 \\
Maofengshan (MFS), PRD & Rural & $23.33^{\circ} \mathrm{N}$ & $113.48^{\circ} \mathrm{E}$ & 535 \\
Nancun (NC), PRD & Suburban & $23.00^{\circ} \mathrm{N}$ & $113.35^{\circ} \mathrm{E}$ & 141 \\
Panyu (PY), PRD & Urban & $22.93^{\circ} \mathrm{N}$ & $113.32^{\circ} \mathrm{E}$ & 12 \\
Dongguan (DG), PRD & Suburban & $22.97^{\circ} \mathrm{N}$ & $113.73^{\circ} \mathrm{E}$ & 43 \\
Xinken, (XK), PRD & Rural & $22.71^{\circ} \mathrm{N}$ & $113.55^{\circ} \mathrm{E}$ & 6.7 \\
Yangshuo (YS), GX & Urban & $24.77^{\circ} \mathrm{N}$ & $110.50^{\circ} \mathrm{E}$ & 75 \\
\hline
\end{tabular}

Fig. 1. Average black carbon concentrations during rainy and dry season sampling periods across different sampling sites in column plots on the map (column plots in different maps are on the same scale and the unit of the associated numbers is $\mu \mathrm{g} \mathrm{m}^{-3}$ ). The table in the figure summarizes characteristics of the sampling sites in this study. (a) Location of the study region in China. (b) Location of the two short-term sites: oceanic site at Yongxing island (YX) and the urban site Yangshuo (YS). (c) Location of the long-term sites in the Pearl River delta, including Maofengshan (MFS), Nancun (NC), Panyu (PY), Dongguan (DG), and Xinken (XK).

presented in the form of $\mathrm{BC}$ mass concentrations. The detailed results of light-absorption measurements are provided in the Supplement.

\section{Results}

\subsection{BC time series}

Hourly variations of $\mathrm{BC}$ and meteorological parameters during the measurement campaigns are shown in Fig. 2a for the rainy season sampling period and Fig. $2 b$ for the dry season sampling period. Concentration distributions in the form of histograms are also shown next to the respective time series plots in Fig. 2. The histograms show that YX has the sharpest frequency distribution among all sites in both the rainy and dry season sampling periods as a result of small temporal variation in $\mathrm{BC}$ concentrations (for more details of the histograms please refer to Fig. S6 in the Supplement). The weak temporal variation characteristic confirmed the nature of $\mathrm{YX}$ as a super-regional background site. For most of time, BC in $\mathrm{YX}$ was at a low level of $\sim 0.5 \mu \mathrm{g} \mathrm{m}^{-3}$ in the rainy season sampling period and $\sim 0.6 \mu \mathrm{g} \mathrm{m}^{-3}$ in the dry season sampling period. A few concentration spikes were observed in YX during the sampling campaign. The cause of these episodic events was investigated by examining $\sigma_{\mathrm{abs}}$ at different wavelength. Absorption Ångström Exponent (AAE) can be considered as an indicator of mixing state. AAE of pure $\mathrm{BC}$ is close to 1 (Moosmuller et al., 2011) and the value increases as $\mathrm{BC}$ mixes with either light absorbing organic carbon, that is, brown carbon (BrC) (Kirchstetter et al., 2004) or nonlight absorbing materials such as sulfate (Lack and Cappa, 2010). The observed average AAE in YX was 0.97 in the 
rainy season sampling period and 1.06 in the dry season sampling period (Fig. S4). This level of AAE is lower than those found over the East China Sea (1.3) (Chung et al., 2012). The temporal variations of AAE and $\sigma_{\mathrm{abs}}$ (Fig. S5) show that the AAE varied from 0.5 to 2 during the sampling period, but the AAE variation was much smaller during two episodic events (14-17 December 2008 and 1-3 January 2009, highlighted in yellow in Fig. S5). This phenomenon suggests that the elevated $\sigma_{\mathrm{abs}}$ during the episodes were likely influenced by more "fresh soot" (such as a passing ship) in comparison to those on the regular days.

The measurements indicated that $\mathrm{BC}$ variations in MFS were independent of the other PRD sites in the rainy season sampling period, as shown in Fig. 2 and also evidenced by the low inter-site correlations in Table 1 . This result suggests that transport of $\mathrm{BC}$ from ground level to an altitude as high as that of MFS (435 m) was not effective. In the dry season sampling period, BC in MFS was weakly correlated with the urban sites PY and NC. The weak BC influence from the source region of PRD on MFS supports the characterization of MFS as a site representing the PRD background conditions. The BC data histogram at MFS in the rainy season sampling period is different from those at the other sites, most likely related to the intermittent data at MFS (Fig. 2a).

$\mathrm{NC}$, located at an altitude of $141 \mathrm{~m}$, could represent the average mixing conditions of air pollutants in the urban region of Guangzhou. This is supported by the high correlations of $\mathrm{BC}$ at $\mathrm{NC}$ with $\mathrm{BC}$ at PY, XK and even DG (Table 1). In the rainy season sampling period, the $\mathrm{BC}$ variation trend at $\mathrm{NC}$ is very similar to those at PY and DG, and the latter two areas are among the major $\mathrm{BC}$ source regions in PRD. In the dry season sampling period, $\mathrm{BC}$ variation trend at $\mathrm{NC}$ was similar to that at DG and a higher inter-site correlation was observed between the two sites ( $r: 0.72$ in the dry season vs. 0.66 in the rainy season sampling period).

By comparison, less removal of $\mathrm{BC}$ in the dry season sampling period makes the diurnal variations of $\mathrm{BC}$ at $\mathrm{PY}$ more closely track the diurnal pattern of transportation emissions. As a result, a broader concentration distribution histogram was observed at PY in the dry season sampling period than at other sites, consistent with the site characteristic of PY being in close proximity to sources. Variation in mixing height plays an important role in affecting BC concentrations for the urban sites. The most severe episodes at PY recorded during the two sampling periods were all associated with low mixing heights. During 30 May to 1 June, BC concentration was extremely high (peak concentration close to $40 \mu \mathrm{g} \mathrm{m}^{-3}$ ) and the mixing height, obtained through balloon sounding in Guangzhou, was only $500 \mathrm{~m}$ (approximately half of those on regular days) (Fig. 2a). Similar episodic events recorded during 26-29 December during the dry season sampling period were observed to coincide with low mixing height, which was only $200-300 \mathrm{~m}$ (Fig. 2b).

At XK, a much smaller percentage of valid data was obtained in the rainy season sampling period due to instrument
Table 1. Inter-site correlation (Pearson's $r$ ) of hourly lightabsorption data in the Pearl River delta region.

\begin{tabular}{lrr}
\hline Pair & Rainy season & Dry season \\
\hline NC vs. PY & 0.83 & 0.49 \\
NC vs. MFS & -0.17 & 0.30 \\
NC vs. DG & 0.66 & 0.72 \\
NC vs. XK & & 0.70 \\
MFS vs. PY & -0.21 & 0.48 \\
MFS vs. XK & & 0.09 \\
MFS vs. DG & -0.11 & 0.17 \\
PY vs. XK & & 0.41 \\
PY vs. DG & 0.65 & 0.48 \\
XK vs. DG & & 0.77 \\
\hline
\end{tabular}

problems. Consequently, only measurements in the dry season sampling period are discussed for XK. In the dry season sampling period, the prevailing northeasterly wind in the PRD region places XK downwind of both DG and NC. BC in XK was well correlated with DG and NC during the dry season sampling period, consistent with the source-receptor relationship among the sites. It is also noted that higher BC level was observed at the rural site XK than that at the suburban surface site DG. This may suggest that there were additional strong BC sources impacting XK.

\subsection{Spatial variation in $\mathrm{BC}$}

The spatial variation in seasonal average $\mathrm{BC}$ concentrations is shown in Fig. 1, with the highest BC occurring at the surface sites in the PRD, followed by the sites at elevated altitudes (i.e., NC and MFS), and the lowest BC at the oceanic site YX Island. The limited measurements of $\mathrm{BC}$ in YS, Guangxi in the rainy season sampling period indicated the average $\mathrm{BC}\left(6.93 \mu \mathrm{g} \mathrm{m}^{-3}\right)$ at this site is comparable to those observed at the PRD urban locations. The BC level in YS is unexpectedly high, considering it is mainly a tourist town. The sampling site at YS was near a major road $(\sim 130 \mathrm{~m})$. Local transportation emissions could be a significant source of measured BC. Emissions from nearby mining and metallurgical industries may have an impact on BC level as well. It is not possible to further speculate the relative contributions of local and regional sources due to the short measurement period and lack of other measurements at YS. The daily average concentration of $\mathrm{BC}$ varied from 0.21 to $2.14 \mu \mathrm{g} \mathrm{m}^{-3}$ at the oceanic site YX Island, 0.71 to $5.43 \mu \mathrm{g} \mathrm{m}^{-3}$ at the PRD regional background site MFS, 2.33 to $15.97 \mu \mathrm{g} \mathrm{m}^{-3}$ at the elevated site $\mathrm{NC}$, and 1.56 to $37.9 \mu \mathrm{g} \mathrm{m}^{-3}$ among the ground sites in South China. In the dry season sampling period, the average $\mathrm{BC}$ reached as high as $12.31 \mu \mathrm{g} \mathrm{m}^{-3}$ at the three PRD ground sites (PY, XK, and DG) and $7.68 \mu \mathrm{g} \mathrm{m}^{-3}$ at the elevated NC site, much higher than the average level $\left(2.88 \mu \mathrm{g} \mathrm{m}^{-3}\right)$ observed at MFS, the mountaintop site. The 
(a)
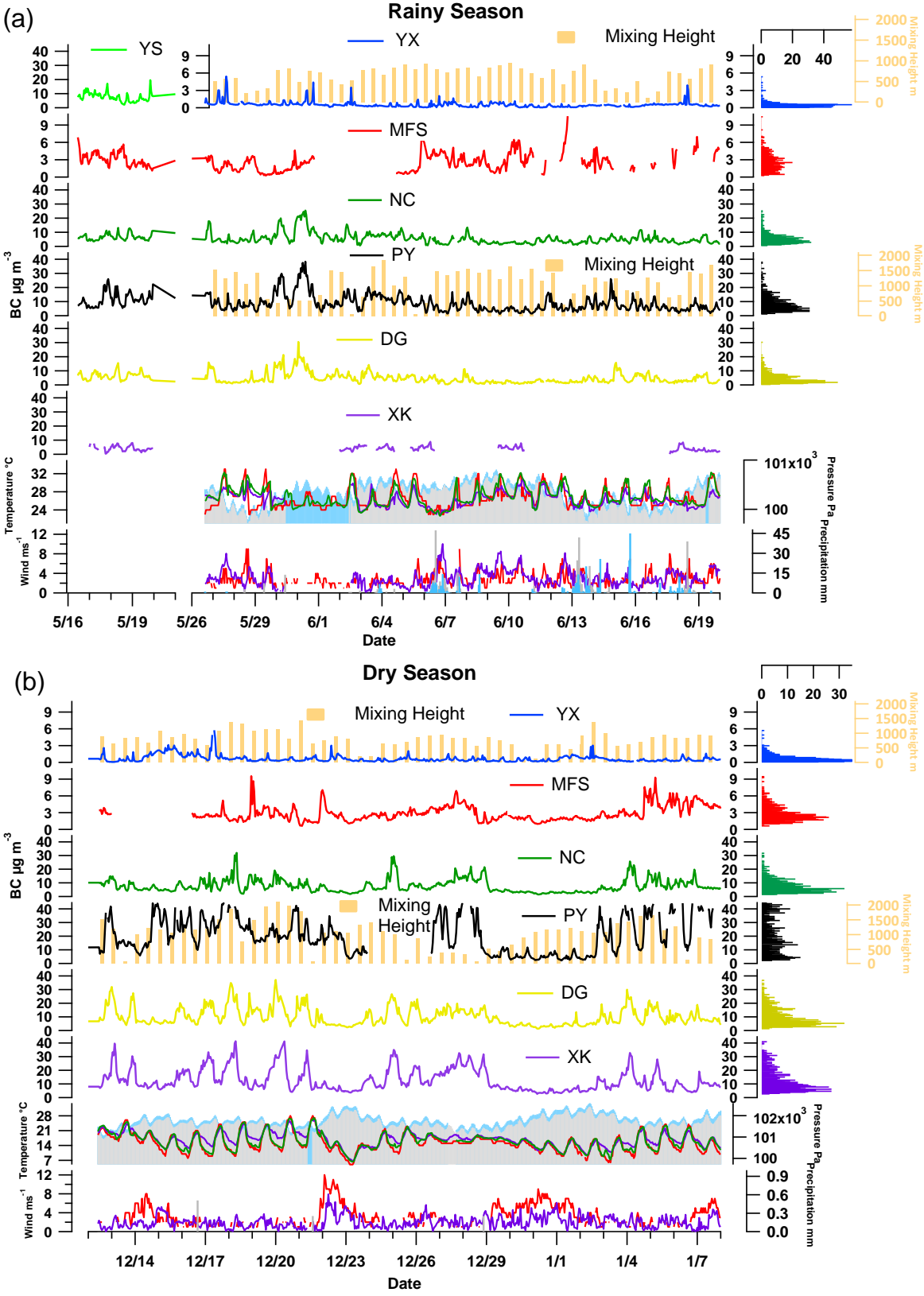

Fig. 2. Time series of BC hourly concentrations, temperature, atmospheric pressure, wind speed, and precipitation amount in the (a) rainy season sampling period and in the (b) dry season sampling period. The bar plots overlaying on the BC plots at YX and PY show the mixing height from balloon measurements. The histograms shown to the right of $\mathrm{BC}$ time series are the frequency distributions of $\mathrm{BC}$ concentrations. In the temperature time series plots, the red curve is measurements for Baiyun airport, $17 \mathrm{~km}$ west to MFS, and is considered to represent meteorological conditions in the northern part of PRD; the green curve is for NC and the purple curve is for XK. In the station pressure plots, the grey areas represent XK and the light blue for NC. In the wind speed plots, red is for the Baiyun airport, purple for XK. In the precipitation plots, grey bars are for XK and light blue for urban Guangzhou.

same vertical spatial gradient was observed in the rainy season sampling period.

Table 2 compares $\mathrm{BC}$ mass concentrations as measured by Aethalometers in this study with those reported in the literature for other locations. The overall campaign average of $\mathrm{BC}$ at the four PRD urban/rural receptor sites is $9.48 \mu \mathrm{g} \mathrm{m}^{-3}$. As shown in Table 2, BC in the PRD is not the highest among urban areas in China, but the level is much higher than urban areas elsewhere in the world, such as Paris $\left(1.66 \mu \mathrm{g} \mathrm{m}^{-3}\right)$ (Healy et al., 2012), New York $\left(1.38 \mu \mathrm{g} \mathrm{m}^{-3}\right.$ ) (Venkatachari et al., 2006), and Mexico City $\left(3.4 \mu \mathrm{g} \mathrm{m}^{-3}\right)$ (Salcedo et al., 2006). 
The campaign average of BC at MFS is similar to the level reported for rural locations in China, such as Hong Kong $\left(2.4 \mu \mathrm{g} \mathrm{m}^{-3}\right)$ (Cheng et al., 2006) and Beijing $\left(2.12 \mu \mathrm{g} \mathrm{m}^{-3}\right.$ by Yan et al. (2008) and $2.37 \mu \mathrm{g} \mathrm{m}^{-3}$ by Zhou et al. (2009).

The BC level at YX Island is comparable to those reported for coastal areas in Europe, such as Baltic Sea $\left(0.6 \mu \mathrm{g} \mathrm{m}^{-3}\right)$ (Bycenkiene et al., 2011) and Mediterranean $\left(\sim 0.7 \mu \mathrm{g} \mathrm{m}^{-3}\right)$ (Saha and Despiau, 2009), but higher than those observed over southwest Indian Ocean $\left(0.43 \mu \mathrm{g} \mathrm{m}^{-3}\right.$ ) (Bhugwant et al., 2000) and the Pacific Ocean $\left(0.006 \mu \mathrm{g} \mathrm{m}^{-3}\right.$, Bodhaine, 1995). The higher BC at YX may partially be attributed to emissions from passing-by marine vessels (Kaluza et al., 2010).

\subsection{Seasonal variation in $\mathrm{BC}$}

For the understanding of seasonal variation of $\mathrm{BC}$, variations in mixing height, monthly average wind flow patterns, and air mass origins are examined. Mixing height data by balloon sounding are available at YX and Guangzhou. The distributions of mixing height data in the two measurement periods are plotted in Fig. S9. Seen from Fig. S9, the mean values of the mixing height at GZ were similar $(\sim 1070 \mathrm{~m}$ in the rainy season sampling period and $\sim 1050 \mathrm{~m}$ in the dry season sampling period), while the most probable mixing heights in the two seasons differed by $\sim 340 \mathrm{~m}$ (1420 vs. $1080 \mathrm{~m}$, respectively). The mean values of the mixing height at $\mathrm{YX}$ were $650 \mathrm{~m}$ in the rainy season and $\sim 800 \mathrm{~m}$ in the dry season sampling period. It appears that the seasonal variation in mixing height was unlikely the driving factor for the observed BC difference in the two sampling periods (Fig. 1).

Figure 4 shows the monthly average wind stream patterns for June and December 2008. The wind stream patterns for other months in 2008 are also examined and shown in Fig. S10. April to May is the transition period of the northeast monsoon to the SCS monsoon, with wind shifting from northeast to southwest over SCS. Under the dominant influence of the SCS monsoon, June to September show highly similar wind patterns, with southwest prevailing wind over SCS. November to March, mainly under the influence of the northeast monsoon, share similar air flow patterns, with northeast prevailing wind over SCS. Thus, the two sampling periods in our study represent the typical wind patterns of their corresponding seasons.

During the rainy season PRD was significantly affected by two different air flows. For most of the time, PRD was affected by the southerly air flow that originated from the vast ocean. On a few days PRD was affected by the northeasterly air flow, which was related to specific weather systems such as typhoons and troughs. For example, during 15-22 May 2008, the tropical typhoon Halong (Fig. S3) was approaching the Philippines, and this large-scale weather system shifted the prevailing wind in PRD to northeasterly. During the dry season, PRD was influenced by the strong northeast monsoon, which brought polluted air masses from the more economically developed regions in the eastern Asia. The reversed wind fields in the rainy and dry seasons result in different dispersion conditions in the PRD region.

Air mass origins were surveyed through plotting air mass back trajectories at the sampling locations for all sampling days using data by the HYSPLIT-4 model (Draxler and Rolph, 2012). YX $\left(16.33^{\circ} \mathrm{N}, 112.83^{\circ} \mathrm{E}\right)$, MFS $\left(23.33^{\circ} \mathrm{N}\right.$, $\left.113.48^{\circ} \mathrm{E}\right)$ and $\mathrm{NC}\left(23.00^{\circ} \mathrm{N}, 113.36^{\circ} \mathrm{E}\right)$ are selected as the reference points for the back trajectories calculation to represent the northern part of SCS and the PRD region. A height of $150 \mathrm{~m}$ is chosen to track the path of air masses which would eventually arrive at the NC and YX in the previous $72 \mathrm{~h}$ while for MFS the height was set as $535 \mathrm{~m}$ to represent the real situation. Figure 3 shows the back trajectories of air masses arriving at $\mathrm{YX}, \mathrm{MFS}$, and $\mathrm{NC}$ in both rainy and dry season sampling periods. Back trajectories at different heights $(100 \mathrm{~m}$, $300 \mathrm{~m}, 500 \mathrm{~m}, 1000 \mathrm{~m}$, and $1500 \mathrm{~m}$ ) were also calculated and shown in Fig. S11. The overall patterns are very similar at different altitudes within the mixing height. The ensemble of back trajectories is also consistent with the monthly average wind stream.

As seen from the $\mathrm{BC}$ measurements, the monsoon system has a significant impact on the seasonal contrast in BC loading in the PRD urban region. Strong seasonal variations were seen at the ground sites (PY and DG) and the elevated site (NC) in PRD where measurements were available in both the rainy and dry seasons. The $\mathrm{BC}$ concentrations were significantly higher in the dry season sampling period, with an average of $12.31 \mu \mathrm{g} \mathrm{m}^{-3}$ in the dry season sampling periods and $6.17 \mu \mathrm{g} \mathrm{m}^{-3}$ in the rainy season sampling period. In the rainy season sampling period, stronger dispersion condition (wind speed: 2.91 vs. $2.15 \mathrm{~m} \mathrm{~s}^{-1}$ in the rainy season vs. dry season sampling periods, respectively) along with abundant rainfall, resulted in stronger removal of BC from the atmosphere in the source region. The total precipitation was $\sim 450 \mathrm{~mm}$ in the rainy sampling period, accounting for $\sim 30 \%$ of the annual precipitation. The BC concentration decreased during rain events (Fig. 2a), indicating that wet deposition was one cause for lower BC in the rainy season sampling period. Take the rain event on 6-7 June 2008 (78 $\mathrm{mm}$ rainfall from 03:00 to 06:00 local time (LT) the next day) as an example. The average $\mathrm{BC}$ concentration in the $24 \mathrm{~h}$ before rain was $5.87 \mu \mathrm{g} \mathrm{m}^{-3}$ at $\mathrm{NC}$ and $9.47 \mu \mathrm{g} \mathrm{m}^{-3}$ at PY. During the $27 \mathrm{~h}$ rain event, the $\mathrm{BC}$ concentration dropped to $2.73 \mu \mathrm{g} \mathrm{m}^{-3}$ at $\mathrm{NC}$ and $5.28 \mu \mathrm{g} \mathrm{m}^{-3}$ at PY.

In comparison, the variations of $\mathrm{BC}$ between the two sampling periods at MFS were small (i.e., $2.62 \mu \mathrm{g} \mathrm{m}^{-3}$ in the rainy season sampling period vs. $2.88 \mu \mathrm{g} \mathrm{m}^{-3}$ in the dry season sampling period). In the dry season MFS is upwind of the PRD region, making it an indicator for super-regional transport (i.e., transport from outside the PRD region). Considering that air masses during cold front are cleaner as they come from high altitude, the $\mathrm{BC}$ average excluding cold front days would be more appropriate to represent the influence from eastern China in the dry season. This concentration 
Table 2. Comparison of BC concentrations $\left(\mu \mathrm{g} \mathrm{m}^{-3}\right)$ obtained by Aethalometers at different locations in the world.

\begin{tabular}{|c|c|c|c|c|c|c|}
\hline Location & Site Characteristics & Sampling Period & Inlet & $\mathrm{BC}$ mass & Correction* & Reference \\
\hline Yongxing Island (YX), China & Oceanic rural, (South China Sea) & $\begin{array}{l}\text { May-Jun } 2008 \\
\text { Dec 2008-Jan2009 }\end{array}$ & $\begin{array}{l}\mathrm{PM}_{2.5} \\
\mathrm{PM}_{10}\end{array}$ & $\begin{array}{l}0.54 \\
0.67\end{array}$ & Yes & This work \\
\hline Maofengshan (MFS), Guangzhou, China & Rural, (Pearl River delta) & $\begin{array}{l}\text { May-Jun } 2008 \\
\text { Dec 2008-Jan } 2009\end{array}$ & $\mathrm{PM}_{10}$ & $\begin{array}{l}2.62 \\
2.88\end{array}$ & Yes & This work \\
\hline Nancun (NC) Guangzhou, China & Suburban, (Pearl River delta) & $\begin{array}{l}\text { May-Jun } 2008 \\
\text { Dec 2008-Jan } 2009 \\
\text { 2004-2007 }\end{array}$ & $\mathrm{PM}_{10}$ & $\begin{array}{l}5.57 \\
7.68 \\
8.42\end{array}$ & Yes & $\begin{array}{l}\text { This work } \\
\text { Wu et al. (2009) }\end{array}$ \\
\hline Panyu (PY), Guangzhou, China & Urban, (Pearl River delta) & $\begin{array}{l}\text { May-Jun } 2008 \\
\text { Dec 2008-Jan } 2009\end{array}$ & $\mathrm{PM}_{10}$ & $\begin{array}{l}8.86 \\
20.21\end{array}$ & Yes & This work \\
\hline Dongguan(DG) China & Suburban, (Pearl River delta) & $\begin{array}{l}\text { May-Jun } 2008 \\
\text { Dec 2008-Jan } 2009\end{array}$ & $\mathrm{PM}_{10}$ & $\begin{array}{l}4.86 \\
10.11\end{array}$ & Yes & This work \\
\hline Xinken (XK), Guangzhou, China & Rural, (Pearl River delta) & Dec 2008-Jan 2009 & $\mathrm{PM}_{10}$ & 12.61 & Yes & This work \\
\hline Yangshuo (YS), China & Urban (Guangxi) & May-Jun 2008 & $\mathrm{PM}_{2.5}$ & 6.93 & Yes & This work \\
\hline Hong Kong, China & Coastal Rural (Pearl River delta) & Jun 2004-May 2005 & $\mathrm{PM}_{2.5}$ & 2.4 & No & Cheng et al. (2006) \\
\hline Mauna Loa, USA & Oceanic rural (Pacific Ocean) & $1990-1993$ & - & 0.006 & Yes & Bodhaine (1995) \\
\hline Toulon, France & Urban Coastal (Mediterranean) & $\begin{array}{l}2005 \text { Winter } \\
2006 \text { Summer }\end{array}$ & $\mathrm{PM}_{2.5}$ & $\begin{array}{l}0.95 \\
0.45\end{array}$ & No & Saha and Despiau (2009) \\
\hline La Réunion Island, French & Urban Coastal (Indian Ocean) & Nov 1996; Apr, Sep 1998 & - & 0.43 & No & Bhugwant et al. (2000) \\
\hline Preila, Lithuania & Coastal Rural (Baltic Sea) & $2008-2009$ & $\mathrm{PM}_{2.5}$ & 0.6 & No & Bycenkiene et al. (2011) \\
\hline Xilinhot, China & Rural (XilinGol League grassland) & $\begin{array}{l}\text { Apr } 2005 \\
\text { Dec } 2005\end{array}$ & - & $\begin{array}{l}2 \\
6.2\end{array}$ & No & Niu and Zhang (2010) \\
\hline Shangdianzi, China & Rural (Beijing, North China Plain) & Apr 2003-Jan 2005 & TSP & 2.12 & Yes & Yan et al. (2008) \\
\hline Changping, China & Rural (Beijing, North China Plain) & Jun-Jul 2005 & $\mathrm{PM}_{2.5}$ & 2.37 & No & Zhou et al. (2009) \\
\hline Taicang, China & Suburban (Shanghai Yangtze delta) & May-Jun 2005 & & 5.47 & & \\
\hline Xi'an, China & Suburban (Guanzhong Plain) & Sep 2003-Aug 2005 & $\mathrm{PM}_{2.5}$ & 14.7 & No & Cao et al. (2009) \\
\hline Fresno, USA & Urban & Jan-Dec 2000 & $\mathrm{PM}_{2.5}$ & 1.17 & No & Watson and Chow (2002) \\
\hline New York, USA & Urban & Jan-Feb 2004 & - & 1.38 & No & Venkatachari et al. (2006) \\
\hline Paris, France & Urban & Jan-Feb 2010 & $\mathrm{PM}_{2.5}$ & 1.66 & Yes & Healy et al. (2012) \\
\hline Mexico City, Mexico & Urban & Apr 2003 & $\mathrm{PM}_{2.5}$ & 3.4 & No & Salcedo et al. (2006) \\
\hline Tomsk, Russia & Urban & $\begin{array}{l}\text { Summer 1997-2008 } \\
\text { Winter 1997-2008 }\end{array}$ & $\mathrm{PM}_{1}$ & $\begin{array}{l}1.9 \\
0.8\end{array}$ & No & Kozlov et al. (2011) \\
\hline
\end{tabular}

* Correction refers to amendment of Aethalometer measurements due to sampling artifacts related to aerosol loading, filter matrix and scattering effect (Coen et al., 2010).

$\left(3.19 \mu \mathrm{g} \mathrm{m}^{-3}\right)$ is $20 \%$ higher than the rainy season sampling period $\left(2.62 \mu \mathrm{g} \mathrm{m}^{-3}\right)$. This may imply that super-regional transport is not the major cause for elevated BC observed at the PRD urban areas in the dry season. The higher abundance of $\mathrm{BC}$ in the air may be associated with weaker dispersion conditions in the dry season (Wu et al., 2008), including wind speed reduction $(\sim 35 \%$ lower than the rainy season sampling period in this study).

The seasonal variation of BC at YX Island was small, with an average $\mathrm{BC}$ of $0.54 \mu \mathrm{g} \mathrm{m}^{-3}$ in the rainy season sampling period and $0.67 \mu \mathrm{g} \mathrm{m}^{-3}$ in the dry season sampling period. In the rainy season, the north-central area of the South China Sea was mainly controlled by the South China Sea monsoon, which originated from the vast ocean. Occasionally in the rainy season, YX Island is under control of the northerly air flow related to the weather system activity, such as in the period of 15-22 May (Fig. 3a). In the dry season YX is downwind of East China Sea, Taiwan Strait and part of the coastal areas of eastern China. The difference in air mass origins may explain the slightly higher BC level in the dry season than the rainy season sampling period.

\subsection{BC diurnal variation}

Diurnal variations of BC are shown in Fig. 5 for the rainy and dry season sampling periods. Two cold front events occurred during the sampling period, evidenced by elevated sta- tion pressure, rapid drop in temperature, and stronger wind (Fig. 2b). During the two cold front periods (period A: 2224 December 2008; period B: 29 December 2008-3 January 2009), the diurnal pattern was very different from the overall diurnal pattern in the dry season sampling period, so the cold front diurnal pattern is plotted separately in Fig. 5.

A discernible diurnal pattern in $\mathrm{BC}$ was observed at the continental urban/suburban sites in that BC concentrations were higher at night and there was a small peak in the early morning. The lowest BC usually occurred in early afternoon in both the rainy and dry season sampling periods. This observation is consistent with observations reported in the previous studies conducted in PRD region (Andreae et al., 2008; Garland et al., 2008; Verma et al., 2010). Higher BC in night is a combined result of lower mixing height after sunset and increased emissions from diesel trucks in the evening, which are associated with the traffic regulation in this region (Garland et al., 2008). In the dry season sampling period, the evening peak at DG and XK was more pronounced and broader than the morning peak, with the evening peak extending to overlap the morning peak. 

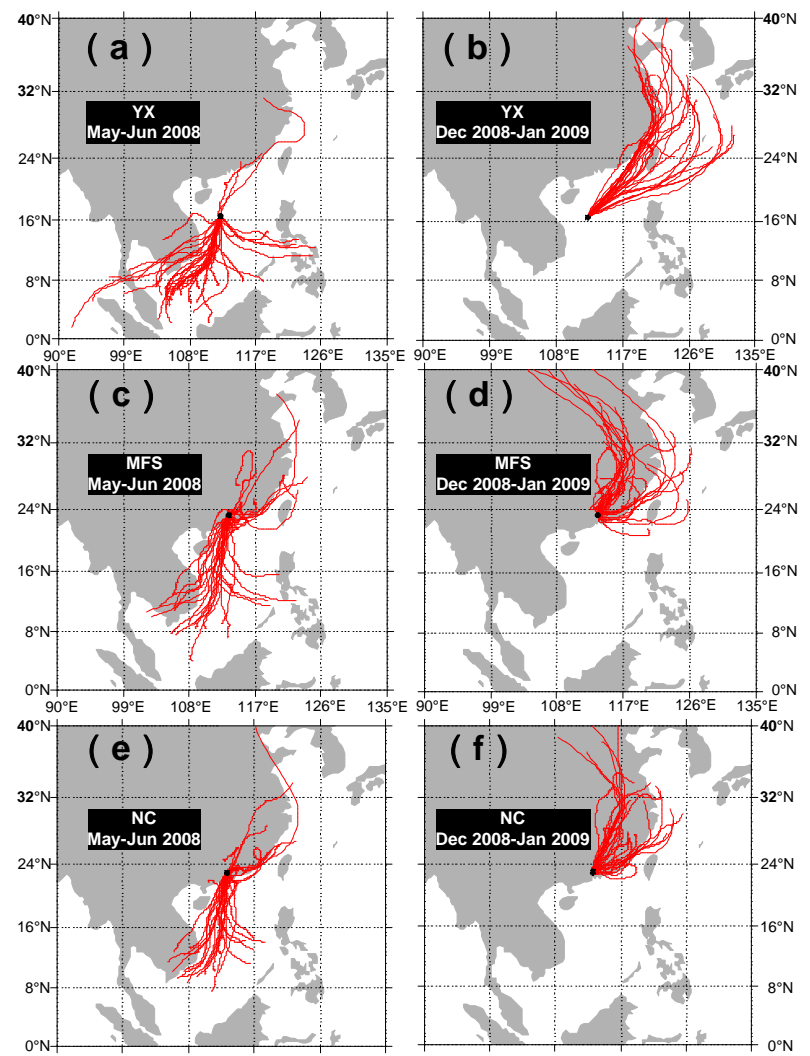

Fig. 3. The back trajectories $(72 \mathrm{~h})$ of the air masses arriving at Yongxing Island and the Pearl River delta at 08:00 a.m. (LT) on each day. (a) Yongxing (YX) island (150 m a.s.l) from 16 May to 20 June 2008; (b) Yongxing (YX) Island (150 m a.s.1.) from 12 December 2008 to 8 January 2009; (c) Maofengshan (MFS) (535 m a.s.1.) from 16 May to 20 June 2008; (d) Maofengshan (MFS) (535 ma.s.l.) from 12 December 2008 to 8 January 2009; (e) Nancun (NC) (150 ma.s.1.) from 16 May to 20 June 2008; (f) Nancun (NC) (150 m a.s.1.) from 12 December 2008 to 8 January 2009.

Passing cold fronts usually bring strong wind and air from high attitudes to the PRD region, resulting in significant reductions in $\mathrm{BC}$ concentrations, which were observed across all the PRD sites as shown in Fig. 2b. During the cold front periods, the evening BC peak was larger than the morning peak at all PRD sites, which may be attributable to two causes. First, the activity intensity of heavy duty vehicles in the nighttime was as high as daytime in Guangzhou urban areas till midnight (Verma et al., 2010). Second, the nighttime wind speed was weaker than daytime wind speed and the mixing height was lower in the nighttime. These two factors acted together, making the nighttime peak more pronounced than the morning peak. As the strong wind during the cold front events would effectively carry away pollutants, providing an opportunity to reveal the fresh local emission pattern in one day. This pattern of peaking in the evening is consistent with the heavy duty vehicles activity pattern in
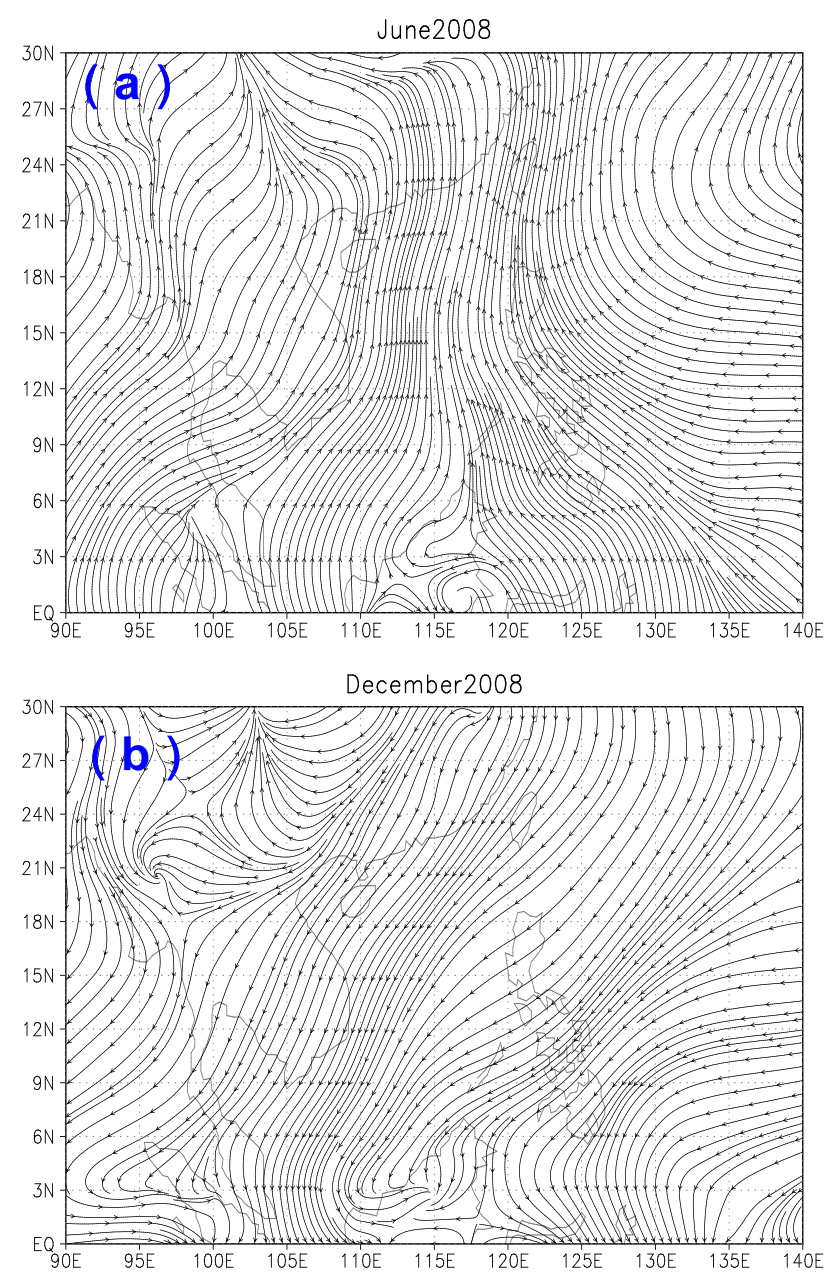

Fig. 4. South China Sea monthly average wind stream maps in (a) June 2008, South China Sea monsoon and (b) December 2008, northeast monsoon.

urban Guangzhou (06:00-24:00), as reported by Verma et al. (2010), implying the significance of BC emissions from the transportation sector. The identical diurnal pattern in DG and XK was consistent with their high inter-site correlation in the dry season sampling period $(r=0.77)$.

At MFS, the PRD background site, the diurnal pattern in the dry season sampling period was very similar to those at the urban/suburban sites in PRD, but the diurnal pattern in the rainy season sampling period was hardly discernible.

A diurnal variation pattern in $\mathrm{BC}$ was discernible at $\mathrm{YX}$, likely a result of operation pattern in the local diesel generator for power. The period with elevated $\mathrm{BC}$ coincided with the office hours (LT 07:00-12:00 and 14:00-18:00). During the non-office hours, BC was almost flat. The two peaks of $\mathrm{BC}$ were higher in the dry season sampling period. 

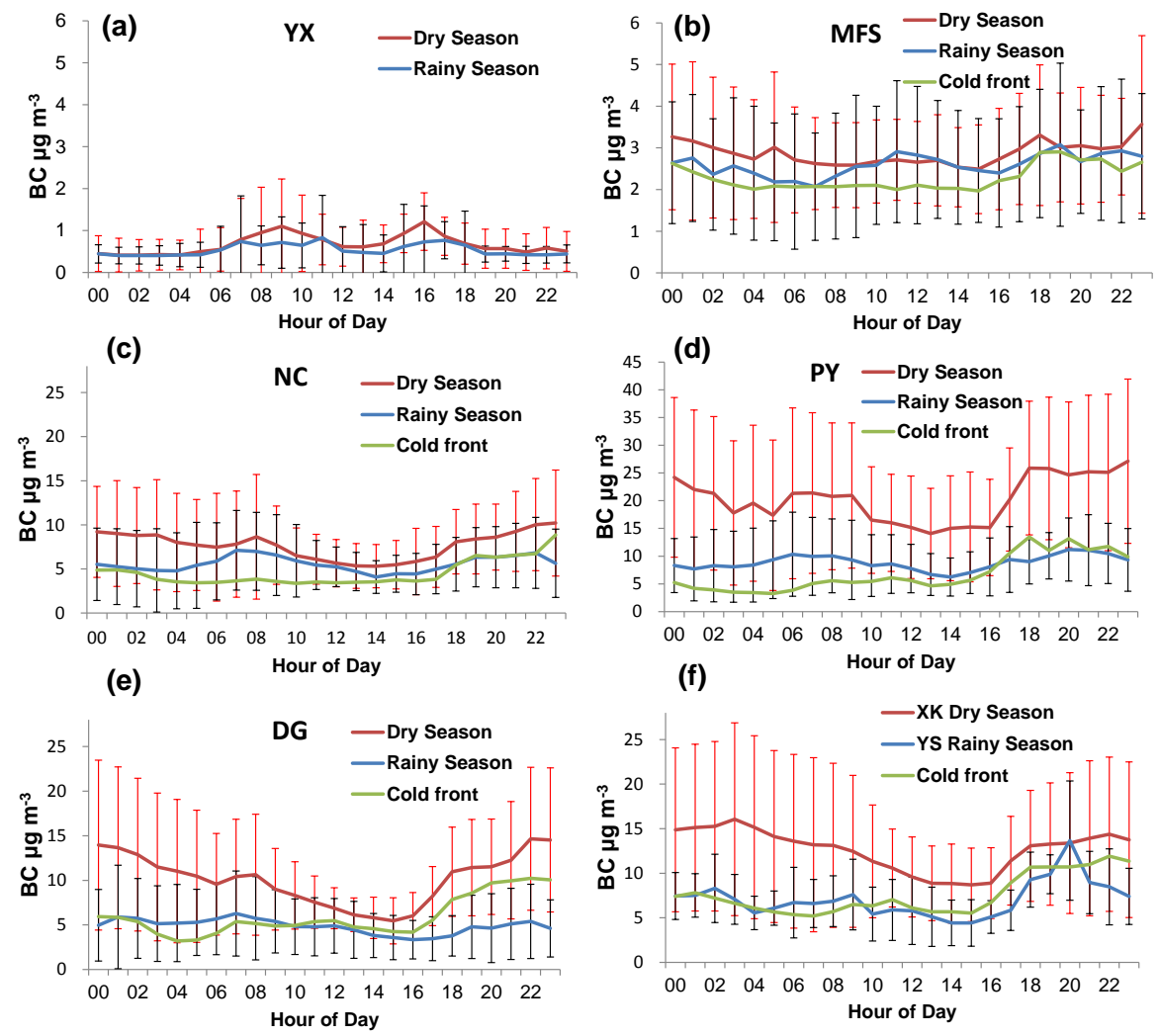

Fig. 5. Diurnal variations of $B C$ concentrations at six monitoring sites in the rainy sampling period, dry season sampling period, and during cold front periods. The error bars represent one standard deviation. The sites are (a) Yongxing Island (YX), (b) Maofengshan (MFS), (c) Nancun (NC), (d) Panyu (PY), (e) Dongguan (DG), (f) Xinken (XK) in the dry season sampling period and Yangshuo (YS) in the rainy season sampling period.

\subsection{BC light absorption}

Light-absorption coefficients ( $\left.\sigma_{\mathrm{abs}}\right)$ data are summarized for the dry and rainy season sampling periods separately in Table 3 and compared in Fig. S1. Daily average $\sigma_{\text {abs }}$ across all sites varied from 4 to $352 \mathrm{Mm}^{-1}$ during the sampling campaign. The continent average of $\sigma_{\text {abs }}$ was tenfold that at the oceanic site YX Island. $\sigma_{\text {abs }}$ observations in this study are compared with those reported in previous studies in Table 3. $\sigma_{\mathrm{abs}}$ in Guangzhou during the dry season sampling period of 2009 was significantly higher than those measured in 2004 for both urban $\left(188 \mathrm{Mm}^{-1}\right.$ in 2009 vs. $91 \mathrm{Mm}^{-1}$ in 2004) and rural $\left(119 \mathrm{Mm}^{-1}\right.$ in 2009 vs. $70 \mathrm{Mm}^{-1}$ in 2004) sites (Andreae et al., 2008; Cheng et al., 2008). The observed $\sigma_{\text {abs }}$ at MFS, a background site in PRD, was $26 \mathrm{Mm}^{-1}$ in the rainy season sampling period and $29 \mathrm{Mm}^{-1}$ in the dry season sampling period, lower than previous observations in the northern rural area of city Guangzhou $\left(42.5 \mathrm{Mm}^{-1}\right)$ (Garland et al., 2008), comparable to those found in Yangtze Delta $\left(23 \mathrm{Mm}^{-1}\right.$ ) (Xu et al., 2002) and in North China Plain $\left(17.5 \mathrm{Mm}^{-1}\right.$ ) (Yan et al., 2008), but higher than those in South East Asia $\left(15 \mathrm{Mm}^{-1}\right)$ (Li et al., 2012). The $\sigma_{\text {abs }}$ observed at the PRD urban area is much higher than those in ur- ban areas around the world, for example, Mexico City (Marley et al., 2009), Tokyo (Nakayama et al., 2010) and a few US cities (Chow et al., 2009; Thompson et al., 2012).

\section{Summary}

In this work we report on the observations of $\mathrm{BC}$ concentrations and absorption coefficients $\left(\sigma_{\mathrm{abs}}\right)$ by Aethalometers on Yongxing Island of South China Sea (a super-regional background site) and five continental locations in southern China mainland during two sampling periods in the rainy season and dry seasons of 2008. BC loading at the South China Sea background site showed little difference between the two sampling periods, with an average of $0.54 \mu \mathrm{g} \mathrm{m}^{-3}$ in the rainy season sampling period and $0.67 \mu \mathrm{g} \mathrm{m}^{-3}$ in the dry season sampling period. Light absorption at $\mathrm{YX}$ is comparable but slightly higher than other coastal areas around the world. The BC level at the PRD background site (Maofengshan at $535 \mathrm{~m}$ a.s.1.) also had a small difference, with $2.88 \mu \mathrm{g} \mathrm{m}^{-3}$ in the dry season and $2.62 \mu \mathrm{g} \mathrm{m}^{-3}$ in the rainy season sampling period. The level at this regional background site is very similar to those found in North China Plain. The average 
Table 3. Comparison of light-absorption measurements $\left(\mathrm{Mm}^{-1}\right)$ at different locations in the world.

\begin{tabular}{|c|c|c|c|c|c|c|c|}
\hline Location & Site characteristics & Sampling Duration & Inlet & Method $^{1}$ & $\sigma_{\text {abs }} \pm$ std @ wavelength & Correction $^{7}$ & Reference \\
\hline Yongxing Island (YX), China & $\begin{array}{l}\text { Oceanic rural, } \\
\text { (South China Sea) }\end{array}$ & $\begin{array}{l}\text { May-Jun } 2008 \\
\text { Dec 2008-Jan } 2009\end{array}$ & $\begin{array}{l}\mathrm{PM}_{2.5} \\
\mathrm{PM}_{10}\end{array}$ & $\mathrm{AE}$ & $\begin{array}{l}7.21 \pm 5.23 @ 532 \mathrm{~nm}^{2} \\
8.37 \pm 5.88 @ 532 \mathrm{~nm}^{2}\end{array}$ & Yes & This work \\
\hline Maofengshan (MFS), Guangzhou, China & $\begin{array}{l}\text { Rural, } \\
\text { (Pearl River delta) }\end{array}$ & $\begin{array}{l}\text { May-Jun } 2008 \\
\text { Dec 2008-Jan } 2009\end{array}$ & $\mathrm{PM}_{10}$ & $\mathrm{AE}$ & $\begin{array}{l}26.45 \pm 13.88 @ 532 \mathrm{~nm}^{2} \\
28.77 \pm 12.71 @ 532 \mathrm{~nm}^{2}\end{array}$ & Yes & This work \\
\hline Nancun (NC), Guangzhou, China & $\begin{array}{l}\text { Suburban, } \\
\text { (Pearl River delta) }\end{array}$ & $\begin{array}{l}\text { May-Jun } 2008 \\
\text { Dec 2008-Jan } 2009\end{array}$ & $\mathrm{PM}_{10}$ & $\mathrm{AE}$ & $\begin{array}{l}53.47 \pm 34.27 @ 532 \mathrm{~nm}^{2} \\
73.10 \pm 44.64 @ 532 \mathrm{~nm}^{2}\end{array}$ & Yes & This work \\
\hline Panyu (PY), Guangzhou, China & $\begin{array}{l}\text { Urban ) } \\
\text { (Pearl River delta }\end{array}$ & $\begin{array}{l}\text { May-Jun } 2008 \\
\text { Dec 2008-Jan } 2009\end{array}$ & $\mathrm{PM}_{10}$ & $\mathrm{AE}$ & $\begin{array}{l}84.03 \pm 53.20 @ 532 \mathrm{~nm}^{2} \\
188.80 \pm 117.30 @ 532 \mathrm{~nm}^{2}\end{array}$ & Yes & This work \\
\hline Dongguan (DG), China & $\begin{array}{l}\text { Suburban, } \\
\text { (Pearl River delta) }\end{array}$ & $\begin{array}{l}\text { May-Jun } 2008 \\
\text { Dec 2008-Jan } 2009\end{array}$ & $\mathrm{PM}_{10}$ & $\mathrm{AE}$ & $\begin{array}{l}47.10 \pm 34.44 @ 532 \mathrm{~nm}^{2} \\
95.53 \pm 60.88 @ 532 \mathrm{~nm}^{2}\end{array}$ & Yes & This work \\
\hline Xinken (XK), Guangzhou, China & $\begin{array}{l}\text { Rural, } \\
\text { (Pearl River delta) }\end{array}$ & Dec 2008-Jan 2009 & $\mathrm{PM}_{10}$ & $\mathrm{AE}$ & $118.63 \pm 73.90 @ 532 \mathrm{~nm}^{2}$ & Yes & This work \\
\hline Yangshuo (YS), China & Urban (Guangxi) & May-Jun 2008 & $\mathrm{PM}_{2.5}$ & $\mathrm{AE}$ & $66.20 \pm 32.18 @ 532 \mathrm{~nm}^{2}$ & Yes & This work \\
\hline Nancun (NC), Guangzhou, China & Suburban & $\begin{array}{l}\text { 2004-2007 (Rainy season) } \\
\text { 2004-2007 (Dry season) }\end{array}$ & $\mathrm{PM}_{10}$ & $\mathrm{AE}$ & $\begin{array}{l}77 \pm 21 @ 532 \mathrm{~nm}^{2} \\
88 \pm 24 @ 532 \mathrm{~nm}^{2}\end{array}$ & Yes & Wu et al. (2009) \\
\hline Guangzhou, China & $\begin{array}{l}\text { Urban } \\
\text { (Pearl River delta) }\end{array}$ & 5 Oct- 5 Nov 2004 & $\mathrm{PM}_{2.5}$ & PAS & $91 \pm 60 @ 532$ nm & - & Andreae et al. (2008) \\
\hline Xinken, Guangzhou, China & Rural (Pearl River delta) & 4 Oct-5 Nov 2004 & $\mathrm{PM}_{10}$ & MAAP & $70 \pm 42 @ 550 \mathrm{~nm}^{3}$ & - & Cheng et al. (2008) \\
\hline Back garden, Guangzhou, China & $\begin{array}{l}\text { Rural } \\
\text { (Pearl River delta) }\end{array}$ & July 2006 & $\mathrm{PM}_{10}$ & PAS & $42.5 \pm 56.5 @ 532 \mathrm{~nm}$ & - & Garland et al. (2008) \\
\hline Hong Kong, China & $\begin{array}{l}\text { Coastal rural } \\
\text { (Pearl River delta) }\end{array}$ & $\begin{array}{l}\text { May-Jun } 1998 \\
\text { Dec 1998-Jan } 1999\end{array}$ & TSP & PSAP & $\begin{array}{l}7.65 @ 565 \mathrm{~nm} \\
31.57 @ 565 \mathrm{~nm}\end{array}$ & No & Man and Shih (2001) \\
\hline Mauna Loa, USA & $\begin{array}{l}\text { Oceanic rural } \\
\text { (Pacific Ocean) }\end{array}$ & $1990-1993$ & - & $\mathrm{AE}$ & 0.058@550nm & Yes & Bodhaine (1995) \\
\hline Barrow,USA & $\begin{array}{l}\text { Coastal rural } \\
\text { (Artic Region) }\end{array}$ & $1988-1993$ & - & & $0.41 @ 550 \mathrm{~nm}$ & & \\
\hline Shangdianzi, Beijing,China & $\begin{array}{l}\text { Rural } \\
\text { (North China Plain) }\end{array}$ & Apr 2003-Jan 2005 & TSP & $\mathrm{AE}$ & $17.5 \pm 13.4 @ 525 \mathrm{~nm}$ & Yes & Yan et al. (2008) \\
\hline Wuqing, Tianjing, China & $\begin{array}{l}\text { Suburban } \\
\text { (North China Plain) }\end{array}$ & $\begin{array}{l}\text { Mar-Apr } 2011 \\
\text { Jul-Aug } 2011\end{array}$ & $\mathrm{PM}_{10}$ & MAAP & $\begin{array}{l}47 \pm 38 @ 637 \mathrm{~nm}^{4} \\
43 \pm 27 @ 637 \mathrm{~nm}^{4}\end{array}$ & - & Ma et al. (2011) \\
\hline Lin'an, Hangzhou, China & $\begin{array}{l}\text { Rural } \\
\text { (Yangtze delta) }\end{array}$ & Nov 1999 & $\mathrm{PM}_{2.5}$ & PSAP & $23 \pm 14 @ 550 \mathrm{~nm}$ & Yes & Xu et al. (2002) \\
\hline Phimai, Thailand & $\begin{array}{l}\text { Rural Indochinese } \\
\text { peninsula }\end{array}$ & Feb-May 2006 & - & $\mathrm{AE}$ & $15 \pm 8 @ 550 \mathrm{~nm}$ & Yes & Li et al. (2012) \\
\hline Montseny, Spin & $\begin{array}{l}\text { Rural } \\
\text { (Mediterranean) }\end{array}$ & Nov 2009-Oct 2010 & $\mathrm{PM}_{10}$ & MAAP & $2.8 \pm 2.2 @ 637 \mathrm{~nm}$ & - & Pandolfi et al. (2011) \\
\hline Tokyo, Japan & Urban & Aug 2007 & - & PSAP & $13.6 \pm 9.2 @ 532 \mathrm{~nm}^{5}$ & Yes & Nakayama et al. (2010) \\
\hline Mexico City, Mexico & Urban & Mar 2006 & - & MAAP & $37 @ 550 \mathrm{~nm}^{6}$ & - & Marley et al. (2009) \\
\hline Fresno, CA, USA & Urban & Aug-Sep 2005 & $\mathrm{PM}_{2.5}$ & PA & $5.22 @ 532 \mathrm{~nm}$ & Yes & Chow et al. (2009) \\
\hline Pasadena, CA, USA & Urban & May-Jun 2010 & $\mathrm{PM}_{2.5}$ & $\mathrm{AM}$ & $4 @ 532$ nm & - & Thompson et al. (2012) \\
\hline
\end{tabular}

concentration of BC in the PRD urban area is $12.31 \mu \mathrm{g} \mathrm{m}^{-3}$ in the dry season sampling period and a significantly lower level $\left(6.17 \mu \mathrm{g} \mathrm{m}^{-3}\right)$ was found in the rainy season sampling period. The $\mathrm{BC}$ level in the PRD region is much higher than other urban areas around the world. Inter-site correlation analysis of $\mathrm{BC}$ measurements reveals that temporal variations of $\mathrm{BC}$ were correlated between certain sites. The strength of the correlations showed seasonal dependency, implying that the monsoon systems play an important role in transport and spatial distribution of BC. A diurnal pattern of higher $\mathrm{BC}$ concentrations was observed at night at most of the PRD sites and at some sites a small peak in the early morning was observed. Our analysis suggests that the diurnal variation pattern is mainly a result of vehicular emissions.

\section{Supplementary material related to this article is available online at http://www.atmos-chem-phys.net/13/ 12257/2013/acp-13-12257-2013-supplement.pdf.}

Acknowledgements. This study is supported by project 973 (2011CB403403) and Natural Science Foundation of China (40775011, U0733004). The authors gratefully acknowledge the NOAA Air Resources Laboratory (ARL) for the provision of the HYSPLIT transport and dispersion model and/or READY website (http://www.arl.noaa.gov/ready.php) used in this publication.

Edited by: F. Q. Yu

\section{References}

Andreae, M. O.: The dark side of aerosols, Nature, 409, 671-672, 2001.

Andreae, M. O., Schmid, O., Yang, H., Chand, D., Yu, J. Z., Zeng, L. M., and Zhang, Y. H.: Optical properties and chemical composition of the atmospheric aerosol in urban Guangzhou, China, Atmos. Environ., 42, 6335-6350, doi:10.1016/j.atmosenv.2008.01.030, 2008.

Babu, S. S. and Moorthy, K. K.: Anthropogenic impact on aerosol black carbon mass concentration at a tropical coastal station, A case study, Curr. Sci. India, 81, 1208-1214, 2001. 
Bhugwant, C., Cachier, H., Bessafi, M., and Leveau, J.: Impact of traffic on black carbon aerosol concentration at la Reunion Island (Southern Indian Ocean), Atmos. Environ., 34, 3463-3473, 2000.

Bodhaine, B. A.: Aerosol Absorption-Measurements at Barrow, Mauna-Loa and the South-Pole, J. Geophys. Res.-Atmos., 100, 8967-8975, 1995.

Bond, T. C. and Bergstrom, R. W.: Light absorption by carbonaceous particles, An investigative review, Aerosol. Sci. Tech., 40, 27-67, doi:10.1080/02786820500421521, 2006.

Bycenkiene, S., Ulevicius, V., and Kecorius, S.: Characteristics of black carbon aerosol mass concentration over the East Baltic region from two-year measurements, J. Environ. Monitor., 13, 1027-1038, doi:10.1039/C0em00480d, 2011.

Cao, J. J., Lee, S. C., Ho, K. F., Zou, S. C., Fung, K., Li, Y., Watson, J. G., and Chow, J. C.: Spatial and seasonal variations of atmospheric organic carbon and elemental carbon in Pearl River Delta Region, China, Atmos. Environ., 38, 4447-4456, doi:10.1016/j.atmosenv.2004.05.016, 2004.

Cao, J. J., Zhu, C. S., Chow, J. C., Watson, J. G., Han, Y. M., Wang, G. H., Shen, Z. X., and An, Z. S.: Black carbon relationships with emissions and meteorology in Xi'an, China, Atmos. Res., 94, 194-202, doi:10.1016/j.atmosres.2009.05.009, 2009.

Cheng, Y., Lee, S. C., Ho, K. F., Wang, Y. Q., Cao, J. J., Chow, J. C., and Watson, J. G.: Black carbon measurement in a coastal area of south China, J. Geophys. Res.-Atmos., 111, D12310, doi:10.1029/2005jd006663, 2006.

Cheng, Y. F., Wiedensohler, A., Eichler, H., Su, H., Gnauk, T., Brueggemann, E., Herrmann, H., Heintzenberg, J., Slanina, J., Tuch, T., Hu, M., and Zhang, Y. H.: Aerosol optical properties and related chemical apportionment at Xinken in Pearl River Delta of China, Atmos. Environ., 42, 6351-6372, doi:10.1016/j.atmosenv.2008.02.034, 2008.

Chi, X. G., Duan, F. K., Dong, S. P., Liu, X. D., and Yu, T.: Concentration level and seasonal variation of organic carbon and elemental carbon in Beijing aerosols, Environmental Monitoring in China, 16, 35-38, 2000 (in Chinese).

Chow, J. C., Watson, J. G., Doraiswamy, P., Chen, L. W. A., Sodeman, D. A., Lowenthal, D. H., Park, K., Arnott, W. P., and Motallebi, N.: Aerosol light absorption, black carbon, and elemental carbon at the Fresno Supersite, California, Atmos. Res., 93, 874887, doi:10.1016/j.atmosres.2009.04.010, 2009.

Chung, C. E., Kim, S.-W., Lee, M., Yoon, S.-C., and Lee, S.: Carbonaceous aerosol AAE inferred from in-situ aerosol measurements at the Gosan $\mathrm{ABC}$ super site, and the implications for brown carbon aerosol, Atmos. Chem. Phys., 12, 6173-6184, doi:10.5194/acp-12-6173-2012, 2012.

Collaud Coen, M., Weingartner, E., Apituley, A., Ceburnis, D., Fierz-Schmidhauser, R., Flentje, H., Henzing, J. S., Jennings, S. G., Moerman, M., Petzold, A., Schmid, O., and Baltensperger, U.: Minimizing light absorption measurement artifacts of the Aethalometer, evaluation of five correction algorithms, Atmos. Meas. Tech., 3, 457-474, doi:10.5194/amt-3-457-2010, 2010.

Cohen, J. B. and Wang, C.: Estimating global black carbon emissions using a top-down Kalman filter approach, J. Geophys. Res., doi:10.1002/2013JD019912, 2013,

Draxler, R. R. and Rolph, G. D.: HYSPLIT (HYbrid Single-Particle Lagrangian Integrated Trajectory) Model access via NOAA
ARL READY Website (http://ready.arl.noaa.gov/HYSPLIT.php) NOAA Air Resources Laboratory, Silver Spring, MD., 2012.

Engling, G. and Gelencser, A.: Atmospheric Brown Clouds, From Local Air Pollution to Climate Change, Elements, 6, 223-228, doi:10.2113/gselements.6.4.223, 2010.

Garland, R. M., Yang, H., Schmid, O., Rose, D., Nowak, A., Achtert, P., Wiedensohler, A., Takegawa, N., Kita, K., Miyazaki, Y., Kondo, Y., Hu, M., Shao, M., Zeng, L. M., Zhang, Y. H., Andreae, M. O., and Pöschl, U.: Aerosol optical properties in a rural environment near the mega-city Guangzhou, China: implications for regional air pollution, radiative forcing and remote sensing, Atmos. Chem. Phys., 8, 5161-5186, doi:10.5194/acp-85161-2008, 2008.

Gundel, L. A., Dod, R. L., Rosen, H., and Novakov, T.: The Relationship between Optical Attenuation and Black Carbon Concentration for Ambient and Source Particles, Sci. Total Environ., 36, 197-202, 1984.

Healy, R. M., Sciare, J., Poulain, L., Kamili, K., Merkel, M., Müller, T., Wiedensohler, A., Eckhardt, S., Stohl, A., Sarda-Estève, R., McGillicuddy, E., O'Connor, I. P., Sodeau, J. R., and Wenger, J. C.: Sources and mixing state of size-resolved elemental carbon particles in a European megacity: Paris, Atmos. Chem. Phys., 12, 1681-1700, doi:10.5194/acp-12-1681-2012, 2012.

IPCC: Climate change 1995: the science of climate change, Cambridge University Press, Cambridge; New York, xii, 572 pp., 1996.

Jacobson, M. Z.: Strong radiative heating due to the mixing state of black carbon in atmospheric aerosols, Nature, 409, 695-697, 2001.

Kaluza, P., Kolzsch, A., Gastner, M. T., and Blasius, B.: The complex network of global cargo ship movements, J. R. Soc. Interface, 7, 1093-1103, doi:10.1098/rsif.2009.0495, 2010.

Kirchstetter, T. W., Novakov, T., and Hobbs, P. V.: Evidence that the spectral dependence of light absorption by aerosols is affected by organic carbon, J. Geophys. Res.-Atmos., 109, , D21208, doi:10.1029/2004jd004999, 2004.

Kozlov, V., Panchenko, M., and Yausheva, E.: Diurnal variations of the submicron aerosol and black carbon in the nearground layer, Atmospheric and Oceanic Optics, 24, 30-38, doi:10.1134/s102485601101009x, 2011.

Lack, D. A. and Cappa, C. D.: Impact of brown and clear carbon on light absorption enhancement, single scatter albedo and absorption wavelength dependence of black carbon, Atmos. Chem. Phys., 10, 4207-4220, doi:10.5194/acp-10-4207-2010, 2010.

Li, C., Tsay, S.-C., Hsu, N. C., Kim, J. Y., Howell, S. G., Huebert, B. J., Ji, Q., Jeong, M.-J., Wang, S.-H., Hansell, R. A., and Bell, S. W.: Characteristics and composition of atmospheric aerosols in Phimai, central Thailand during BASE-ASIA, Atmos. Environ., 78, 60-71, doi:10.1016/j.atmosenv.2012.04.003, 2012.

Lohmann, U. and Lesins, G.: Stronger constraints on the anthropogenic indirect aerosol effect, Science, 298, 1012-1015, 2002.

Lou, S. J., Mao, J. T., and Wang, M. H.: Observational study of black carbon aerosol in Beijing, Acta Scientiae Circumstantiae, 25, 17-22, 2005.

Ma, N., Zhao, C. S., Nowak, A., Müller, T., Pfeifer, S., Cheng, Y. F., Deng, Z.Z., Liu, P. F., Xu, W. Y., Ran, L., Yan, P., Göbel, T., Hallbauer, E., Mildenberger, K., Henning, S., Yu, J., Chen, L. L., Zhou, X. J., Stratmann, F., and Wiedensohler, A.: Aerosol optical properties in the North China Plain during HaChi campaign: 
an in-situ optical closure study, Atmos. Chem. Phys., 11, 59595973, doi:10.5194/acp-11-5959-2011, 2011.

Man, C. K. and Shih, M. Y.: Light scattering and absorption properties of aerosol particles in Hong Kong, J. Aerosol. Sci., 32, 795-804, 2001.

Marley, N. A., Gaffney, J. S., Castro, T., Salcido, A., and Frederick, J.: Measurements of aerosol absorption and scattering in the Mexico City Metropolitan Area during the MILAGRO field campaign: a comparison of results from the T0 and T1 sites, Atmos. Chem. Phys., 9, 189-206, doi:10.5194/acp-9-189-2009, 2009.

Menon, S., Hansen, J., Nazarenko, L., and Luo, Y. F.: Climate effects of black carbon aerosols in China and India, Science, 297, 2250-2253, 2002.

Moosmüller, H., Chakrabarty, R. K., and Arnott, W. P.: Aerosol light absorption and its measurement, A review, J. Quant. Spectrosc. Ra., 110, 844-878, 2009.

Moosmüller, H., Chakrabarty, R. K., Ehlers, K. M., and Arnott, W. P.: Absorption Ångström coefficient, brown carbon, and aerosols: basic concepts, bulk matter, and spherical particles, Atmos. Chem. Phys., 11, 1217-1225, doi:10.5194/acp-11-12172011, 2011.

Müller, T., Henzing, J. S., de Leeuw, G., Wiedensohler, A., Alastuey, A., Angelov, H., Bizjak, M., Collaud Coen, M., Engström, J. E., Gruening, C., Hillamo, R., Hoffer, A., Imre, K., Ivanow, P., Jennings, G., Sun, J. Y., Kalivitis, N., Karlsson, H., Komppula, M., Laj, P., Li, S.-M., Lunder, C., Marinoni, A., Martins dos Santos, S., Moerman, M., Nowak, A., Ogren, J. A., Petzold, A., Pichon, J. M., Rodriquez, S., Sharma, S., Sheridan, P. J., Teinilä, K., Tuch, T., Viana, M., Virkkula, A., Weingartner, E., Wilhelm, R., and Wang, Y. Q.: Characterization and intercomparison of aerosol absorption photometers: result of two intercomparison workshops, Atmos. Meas. Tech., 4, 245-268, doi:10.5194/amt-4-245-2011, 2011.

Nakayama, T., Hagino, R., Matsumi, Y., Sakamoto, Y., Kawasaki, M., Yamazaki, A., Uchiyama, A., Kudo, R., Moteki, N., Kondo, Y., and Tonokura, K.: Measurements of aerosol optical properties in central Tokyo during summertime using cavity ring-down spectroscopy, Comparison with conventional techniques, Atmos. Environ., 44, 3034-3042, doi:10.1016/j.atmosenv.2010.05.008, 2010.

Niu, S. J. and Zhang, Q. Y.: Scattering and absorption coefficients of aerosols in a semi-arid area in China, Diurnal cycle, seasonal variability and dust events, Asia-Pac J. Atmos. Sci., 46, 65-1, doi:10.1007/s13143-010-0007-2, 2010.

Pandolfi, M., Cusack, M., Alastuey, A., and Querol, X.: Variability of aerosol optical properties in the Western Mediterranean Basin, Atmos. Chem. Phys., 11, 8189-8203, doi:10.5194/acp-11-81892011, 2011.

Penner, J. E., Dong, X. Q., and Chen, Y.: Observational evidence of a change in radiative forcing due to the indirect aerosol effect, Nature, 427, 231-234, doi:10.1038/Nature02234, 2004.

Qin, S. G., Tang, J., and Wen, Y. P.: Black Carbon and Its Importance in Climate Change Studies, Meteorology, 27, 3-7, 2001 (in Chinese).

Ramanathan, V., Crutzen, P. J., Mitra, A. P., and Sikka, D.: The Indian Ocean Experiment and the Asian Brown Cloud, Curr. Sci. India, 83, 947-955, 2002.
Ramanathan, V. and Carmichael, G.: Global and regional climate changes due to black carbon, Nat. Geosci., 1, 221-227, doi:10.1038/Ngeo156, 2008.

Reddy, M. S. and Venkataraman, C.: Atmospheric optical and radiative effects of anthropogenic aerosol constituents from India, Atmos. Environ., 34, 4511-4523, 2000.

Saha, A. and Despiau, S.: Seasonal and diurnal variations of black carbon aerosols over a Mediterranean coastal zone, Atmos. Res., 92, 27-41, doi:10.1016/j.atmosres.2008.07.007, 2009.

Salcedo, D., Onasch, T. B., Dzepina, K., Canagaratna, M. R., Zhang, Q., Huffman, J. A., DeCarlo, P. F., Jayne, J. T., Mortimer, P., Worsnop, D. R., Kolb, C. E., Johnson, K. S., Zuberi, B., Marr, L. C., Volkamer, R., Molina, L. T., Molina, M. J., Cardenas, B., Bernabé, R. M., Márquez, C., Gaffney, J. S., Marley, N. A., Laskin, A., Shutthanandan, V., Xie, Y., Brune, W., Lesher, R., Shirley, T., and Jimenez, J. L.: Characterization of ambient aerosols in Mexico City during the MCMA-2003 campaign with Aerosol Mass Spectrometry: results from the CENICA Supersite, Atmos. Chem. Phys., 6, 925-946, doi:10.5194/acp-6-925-2006, 2006.

Sun, H., Zhang, Z., Pei, L. M., and Miao, W. Q.: A Preliminary Investigation of the Pollution of Organic Carbon and Elemental Carbon in Aberosol in Qiqihar, Journal of Science of Teachers College and University, 17, 57-61, 1997 (in Chinese).

Tang, J., Wen, Y. P., Zhou, L. X., Qi, D. L., Zheng, M., Trivett, N., and Wallgren, E.: Observational study of black carbon in clean air area of western China, J. Appl. Meteorol. Sci., 10, 160-170, 1999 (in Chinese).

Tao, W. K., Chen, J. P., Li, Z. Q., Wang, C., and Zhang, C. D.: Impact of Aerosols on Convective Clouds and Precipitation, Rev. Geophys., 50, Rg2001, doi:10.1029/2011rg000369, 2012.

Thompson, J. E., Hayes, P. L., Jimenez, K. A. J. L., Zhang, X., Liu, J., Weber, R. J., and Buseck, P. R.: Aerosol Optical Properties at Pasadena, CA During CalNex 2010, Atmos. Environ., 55, 190 200, doi:10.1016/j.atmosenv.2012.03.011, 2012.

Venkatachari, P., Zhou, L. M., Hopke, P. K., Felton, D., Rattigan, O. V., Schwab, J. J., and Demerjian, K. L.: Spatial and temporal variability of black carbon in New York City, J. Geophys. Res.Atmos., 111, D10s05, doi:10.1029/2005jd006314, 2006.

Verma, R. L., Sahu, L. K., Kondo, Y., Takegawa, N., Han, S., Jung, J. S., Kim, Y. J., Fan, S., Sugimoto, N., Shammaa, M. H., Zhang, Y. H., and Zhao, Y.: Temporal variations of black carbon in Guangzhou, China, in summer 2006, Atmos. Chem. Phys., 10, 6471-6485, doi:10.5194/acp-10-6471-2010, 2010.

Wang, C.: Impact of anthropogenic absorbing aerosols on clouds and precipitation, A review of recent progresses, Atmos. Res., 122, 237-249, doi:10.1016/j.atmosres.2012.11.005, 2013.

Wang, G. C., Kong, Q. X., Ren, L. X., Gu, Z. F., and Emilenko, A.: Black Carbon Aerosol and Its Variations in the Urban Atmosphere in Beijing area, The Chinese Journal of Process Engineering, 2, 284-288, 2002.

Watson, J. G. and Chow, J. C.: Comparison and evaluation of in situ and filter carbon measurements at the Fresno Supersite, J. Geophys. Res.-Atmos., 107, 8341, doi:10.1029/2001jd000573, 2002.

Wu, D.: A Discussion on Difference between Haze and Fog and Warning of Ash Haze Weather, Meteorological Monthly, 31, 3 7, 2005 (in Chinese). 
Wu, D., Tie, X. X., Li, C. C., Ying, Z. M., Lau, A. K. H., Huang, J., Deng, X. J., and Bi, X. Y.: An extremely low visibility event over the Guangzhou region, A case study, Atmos. Environ., 39, 6568-6577, doi:10.1016/j.atmosenv.2005.07.061, 2005.

Wu, D., Bi, X. Y., Deng, X. J., Li, F., Tan, H. B., Liao, G. L., and Huang, J.: Effect of atmospheric haze on the deterioration of visibility over the Pearl River Delta, Acta Meteorol. Sin., 21, 215223, 2007.

Wu, D., Liao, G., Deng, X., Bi, X., Tan, H., Li, F., Jiang, C., Xia, D., and Fan, S.: Transport Condition of Surface Layer Under Haze Weather over the Pearl River Delta, J. Appl. Meterol. Sci., 19, 1-9, 2008 (in Chinese).

Wu, D., Mao, J. T., Deng, X. J., Tie, X. X., Zhang, Y. H., Zeng, L. M., Li, F., Tan, H. B., Bi, X. Y., Huang, X. Y., Chen, J., and Deng, T.: Black carbon aerosols and their radiative properties in the Pearl River Delta region, Sci. China Ser. D., 52, 1152-1163, doi:10.1007/s11430-009-0115-y, 2009.
Xu, J., Bergin, M. H., Yu, X., Liu, G., Zhao, J., Carrico, C. M., and Baumann, K.: Measurement of aerosol chemical, physical and radiative properties in the Yangtze delta region of China, Atmos. Environ., 36, 161-173, 2002.

Yan, P., Tang, J., Huang, J., Mao, J. T., Zhou, X.J., Liu, Q., Wang, Z. F., and Zhou, H. G.: The measurement of aerosol optical properties at a rural site in Northern China, Atmos. Chem. Phys., 8, 2229-2242, doi:10.5194/acp-8-2229-2008, 2008.

Zhou, X. H., Cao, J., Wang, T., Wu, W. S., and Wang, W. X.: Measurement of black carbon aerosols near two Chinese megacities and the implications for improving emission inventories, Atmos. Environ., 43, 3918-3924, doi:10.1016/j.atmosenv.2009.04.062, 2009.

Zhu, Z., Shen, Q. H., and Zhang, D. N.: Distribution of Particulate Carbon in Aerosol at Pudong New Area, Shanghai Environmental Sciences, 15, 12-15, 1996. 